\title{
Political choices during the European Parliament elections as a model for civic responsibility of young people in Poland - the context of formal education
}

\section{KEYWORDS}

civic responsibility, Citizenship Education, Civics, the European Parliament elections

\begin{abstract}
Bożena Kanclerz, Political choices during the European Parliament elections as a model for civic responsibility of young people in Poland - the context of formal education. Culture - Society - Education no. 2(18) 2020, Poznań 2020, pp. 235-249, Adam Mickiewicz University Press. ISSN 2300-0422. DOI 10.14746/kse.2020.18.9.2.

The main axis of the narration in this article is the analysis of the electoral activity of young Poles from the perspective of the formal program of Citizenship Education in the area of shaping the attitudes of young people as active voters. The first part of the article presents the context of Polish civil society and the electoral activity of young Poles. The Author connects the analyses of youth electoral patterns to with the assessment of effectiveness of formal education, including textbook messages, in shaping and developing civic engagement in youth. The article presents the analysis of textbooks for civic education, as well as indicates some non-textual contexts for implementing civic education in Poland. The analysis of citizenship education textbooks becomes an opportunity to approximate multi-faceted challenge of shaping civil attitudes among young people in Poland.
\end{abstract}




\section{Introduction}

The main axis of the narration in this article is to present the electoral activity of young Poles in comparison with the formal program of Citizenship Education in the field of shaping the attitudes of active voters. This topic was discussed on the basis of the European Parliament elections as one of the many dimensions of civic responsibility of young generation. In the context of the above, the most important thread I would like to outline in the article is the need for continuous improvement, at many levels and in many dimensions, of formal education. Because in comparison with the statistics (quantitative data) and views presented by young people, both on the politics itself and the wider context of social life, we remain with many dilemmas and doubts regarding the effectiveness of provided educational services.

The category of civic responsibility is understood in the literature on the subject in an extremely diverse way, depending both on the context of the research being carried out and on the scientific orientation of the defining one. However, the great number of definitions of the category of civic responsibility has a lot of advantages, especially for the researcher of contemporary youth, who assumed that the concept evolves and changes depending on the times when the research is conducted. In the case of the category of civic responsibility, however, the abundance of definitions leads, as E. Wnuk-Lipiński stresses, to a distinction between two types of operationalisation of the concept. According to the first approach, which is a philosophical discourse, civic responsibility is understood "in moral terms as a virtue or a set of norms and values that have the nature of an ethos, a specific ethics or a set of certain normative and cognitive characteristics and dispositions of individuals, emphasizing their active, operational and practical aspect" (Bukowska, Wnuk-Lipiński, 2009: 25). The second approach characteristic of socio-political theories is defined by civic responsibility as a relatively permanent tendency or disposition to take specific actions. "Civic responsibility is usually defined in psychosocial personality categories as an attitude, i.e. a relatively permanent structure of beliefs relating to a specific object or situation and predisposing a person to respond to them in a specific way" (Rokeach, 1968: 112, quoted after Bukowska, Wnuk-Lipiński, 2009: 25). In my article, I adopted the notion of civic responsibility understood by E. Wnuk-Lipiński as an attitude expressing itself in activity, responsibility and involvement in the creation of public goods (Wnuk-Lipiński, 2005: 105). This category is extremely dynamic and remains an interesting research issue in the context of youth as a social group, to which a significant role is attributed in the creation of contemporary society (K. Mannheim, Z. Kwieciński, 
K. Szafraniec), but also in the context of non-traditional forms of civic responsibility, such as those related to the development of new technologies. On the other hand, in the individual dimension, civic responsibility as an attitude contributes not only to the development of an individual (his or her life goals and their realization), but more broadly it is of great importance for the formation of civic society.

For a researcher of youth in the context of their formal Citizenship Education, it will be justified to adopt a definition which refers to the civic responsibility as a specific attitude. Especially when we take into account the context of the tasks for education, about which J. Nikitorowicz wrote as follows "promoting and creating a continuous paradigm of coexistence, understanding, cooperation and collaboration with others, in order to achieve a post-conventional level, open to trans-national civic responsibility" (2009: 24). These words sound very much alive today, especially in the current atmosphere of resurgent nationalism or authoritarianism, as well as quite strongly rooted anti-European attitudes or denial of the European community. Preparation for civic activity, including participation in elections, as one of the most important democratic procedures, is therefore, an important and crucial task in social, philosophical and educational (pedagogical) terms. The value of civic activity was also recognized by political decision-makers, and raising to values by shaping civic and patriotic attitudes became one of the six basic directions for implementing the state's educational policy in the school year $2019 / 2020^{1}$. In the context of the subject under consideration, it is obvious that a possible evaluation or analysis of the Citizenship Education conducted today, both formal and non-formal one (upbringing and socialization in the family or peer environment), will be possible when primary and secondary school students become voters. However, it is worth taking into account that electoral activity and its character (quantitative and qualitative dimension) may constitute important information about the contemporary generation of young people, their involvement and responsibility. The data also illustrate the political views represented by young people, thus indicating the selected features of this voting social group. It should also be stressed that the electoral law as a basic feature of civic status, as the sociologist J. Raciborski writes, remains in the individual dimension one of the important components of civic identity (Raciborski, 2011: 36). Therefore, it is worthwhile to analyse in the context of the future how today's young voters function in the space of democratic procedures in order to be able to address the tasks potentially faced by facilitators of education and citizenship education. It is not without reason that I have made the elections to the European Parliament the

\footnotetext{
1 From the website men.gov.pl, accessed on 12.09.2019.
} 
subject of my deliberations. It seems that this is a space where there is still a lot to be done in terms of education and upbringing. Little social interest in the elections of Members of the European Parliament ${ }^{2}$, and an increasing proportion of Poles who want to leave the European Union ${ }^{3}$, These are just some of the factors that are worth highlighting when analysing election results, especially in the context of Citizenship Education.

\section{Social context of the elections to the European Parliament in Poland}

Participation in elections is one of the elements of involvement of modern generation in the creation of civic society. Therefore, it seems important to map out closer the social context of the last elections to the European Parliament, which took place on 26 May 2019. It is impossible to make a comprehensive overview of the social and political situation, but it is worth pointing out some important facts that appear in sociological and political analyses, which researchers point out as important in the perspective of the analysis of the election results. First of all, it should be pointed out that the election campaign for the European Parliament took place in the atmosphere of political and social divisions, without any well-established electoral programmes. The programme solutions were sidelined and the parties focused on strengthening the divisions. Such a strategy, called the spoils system (Wojtasik, 2010: 18) enhances in the electors, also the young ones, a suspicious attitude towards politicians (Kopińska, 2019: 149). What is quite interesting in the context of the elections to the European Parliament, the campaign was

2 There has been a noticeable increase in the number of voters in elections to the European Parliament over the years. In 2004 the turnout was 20,87\%, in 2009 24,53\%, in 2014 23,83\% and in 2019 45,68\% [data from the website https://europarl.europa.eu/election-results-2019/pl/frekwencja/ accessed on 21.09.2019]. There is therefore a significant upward trend, but in the area of democratic action it has never been possible to reach the limit of $50 \%$ of voting rights. Thus, the growth itself is positive, but the lack of participation of more than half of those entitled to vote is still a need to promote electoral right.

${ }^{3} 54 \%$ of respondents in the 2017 survey were in favour of staying in the EU. As early as 2016, $61 \%$ of the surveyed Poles expressed such a declaration. In 2017, 27\% of respondents declared their willingness to leave the EU, while in 2016 it was $20 \%$ of respondents. The survey was conducted for Wirtualna Polska portal on Ariadna panel on 17-20 November 2017. National sample of persons aged 18 and over $(\mathrm{N}=1060)$. Figures selected according to population representation for gender, age, education and size of place of residence. Method: CAWI from the website https://opinie.wp.pl/corazwiecej-polakow-chce-wyjsc-z-unii-europejskiej-sondaz-dla-wp-6191203265427073a [accessed on 21.09.2019]. 
dominated by world views ${ }^{4}$. The politicians' statements highlighted anti-European views (including the Confederation Party) or views signalling the need for reforms in the European Union structures (including Law and Justice Party). Among publicists, sociologists and political scientists, the prevailing conviction was that elections to the European Parliament are a plebiscite of popularity of political parties and politicians and not the choice of a European program. The public debate took place in an atmosphere of political 'fight', harsh language, insults and ad personal arguments. This was yet another extra-territorial debate which contributed to the discouragement and lack of interest in the campaign, due to low confidence in politicians (Czapiński, Panek, 2015). The division into "us" and "them" was also reinforced in the campaign, which, in the subjective opinion of the author, was supposed to continue to divide Poles, especially by looking for the so-called "hooks", referring both to political offenses and directly to private life of politicians. Thus, we had an example of an overly "dirty" campaign in the context of political marketing and, at the same time, an extremely "vague" one, without making any concrete plans and programmes, as if it was just a prelude to the proper election run to the Sejm and Senate. It should be emphasized that this general characteristics, is only an indication of the social and political climate that we experienced during the European Parliament election campaign. In the perspective of the polarisation of society's views, i.e. the so-called Polish-Polish ${ }^{5}$ war, which also affects a large group of young people (e.g. Equality marches versus National marches, Black Friday versus Life marches) and in the situation when anti-European or Euro-sceptical programmes are becoming more and more popular, it is worth analysing how Polish youth elected representatives to the European Parliament.

\section{Young people vote!}

Referring first of all to quantitative data, the trend that we have been encountering for many years in the analysis of youth (Szafraniec, 2011, 2017) has been confirmed, i.e. in the 18-29 age group we have observed the lowest turnout of all the age groups taking part in elections. In the elections to the European Parliament

\footnotetext{
${ }^{4}$ Publicists pointed out that this issue was really about preparing politicians for the upcoming elections to the Sejm and Senate, from the website: https://wyborcza.pl/naszaeuropa/7,168189,24795688, czy-pis-kupuje-glosy-a-koalicja-europejska-nie-ma-programu.html [accessed on 21.10.2019].

${ }_{5}$ The term that appeared in journalism in connection with strongly outlined divisions in the political, world-view or ideological sphere. Most often understood as a division into: we supporters of the ruling party (PiS) and the rest of Poland (opponents of the ruling party), see among others: https://natemat.pl/181779,slownik-wojny-polsko-polskiej [accessed on 12.09.2019].
} 
in 2019, the overall turnout was $45,68 \%$ and was the highest of the previous ones. However, only one in four young respondents took part in the elections (turnout $27,6 \%)^{6}$. This significant difference should trigger reflections as we have not seen any improvement in the statistics for many years. However, the above results beg for a question: is the (non-electoral) activity of the youngest really lower than of other age groups? (Kopińska, 2019: 150). Of course, referring to quantitative results, we could doubt the validity of such a question, but interesting interpretations in this case are provided by both K. Szafraniec (2012) and V. Kopińska (2019). These authors are aware that the activity of young people is currently completely different and no longer conventional. The majority of activities, including those related to social and political activity, are undertaken on the Internet. As K. Szafraniec points out, this activity is more dispersed, less formalised and less visible. It should be stressed, however, that such a style of participation translates into real election results, in which absent people still do not have a vote and those who accept the traditional form of voting in the polling station become, in a way, the voice of the young generation.

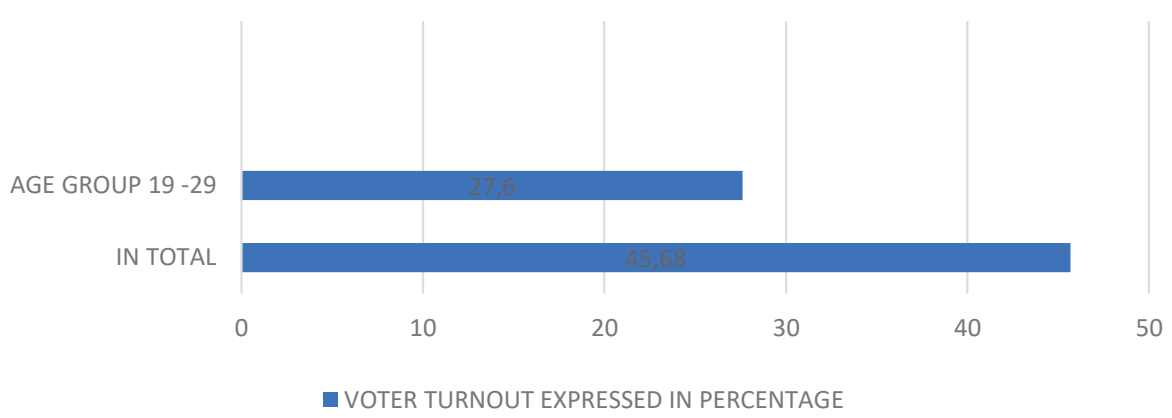

Fig. 1. Voter turnout in the European Parliament elections

Source: own compilation based on the State Election Committee results (from the website https://pkw.gov.pl/ accessed on 12.07.2019) and Ipsos (from the website https://www.ipsos.com/pl-pl [access: 12.07.2019]).

So how did the vote of the young generation develop based on the analysis of the votes cast for the various parties running for election? First of all, in the 18-29 age group, there is a fairly even distribution between young Law and Justice Party voters and the Civic Coalition Party voters. Slightly with a result of $28,4 \%$, Law and Justice won in this group. However, referring to all voters, the votes among young people were much more dispersed, as the third place with a very high result

\footnotetext{
${ }^{6}$ On the basis of PKW results (from the website https://pkw.gov.pl/ accessed on 12.07.2019) and Ipsos (from the website https://www.ipsos.com/pl-pl accessed on 12.07.2019).
} 
was reached by Confederation Party, with $18,5 \%$ of votes. A good result in this age group was also recorded by R. Biedroń and his party (13,7\% of votes) and P. Kukiz, who received $8,3 \%$ of the votes of young people.

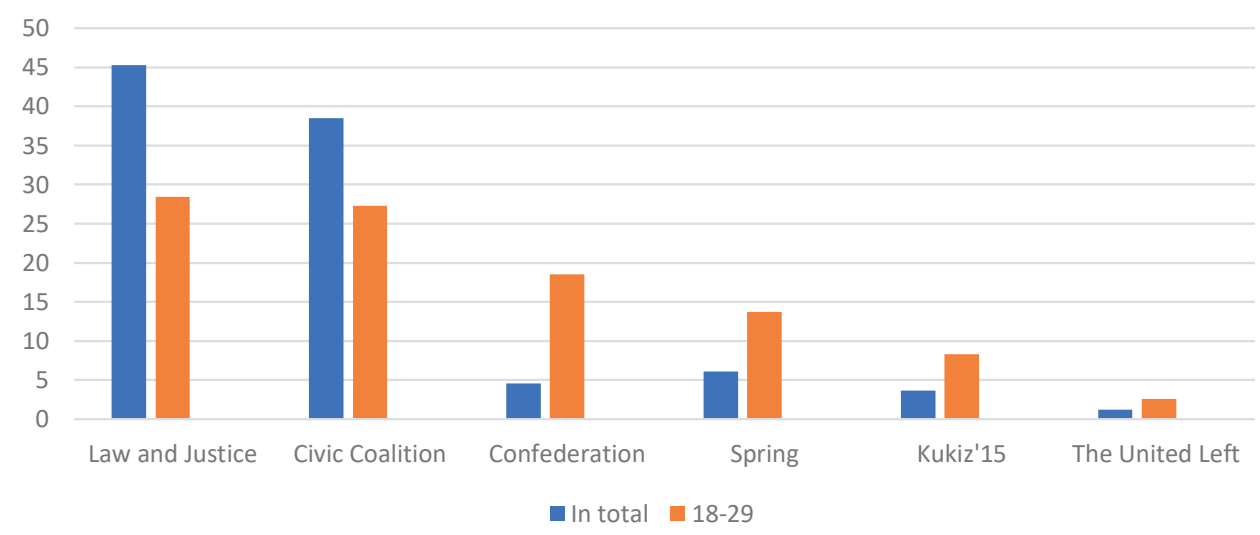

Fig. 2. Results of particular parties in the European Parliament elections

Source: own compilation based on The State Election Committee results (from the website https://pkw.gov.pl/ accessed on 12.07.2019) and Ipsos (from the website https://www.ipsos.com/pl-pl [access: 12.07.2019]).

In the total voting population, more than $80 \%$ of the voters cast their votes for the two groups: Law and Justice and the Civic Coalition. Among the Poles who voted, other parties did not gain a significant approval of the voters. Confederation, which was very popular among young voters, did not exceed the threshold of $5 \%$ of votes in its national results.

When analyzing the above results, it is worth noting two issues - evaluating the results of the elections in terms of quantity and their qualitative dimension. First of all, we should constantly ask ourselves about the low turnout among young voters. Only one in four young people in 18-29 age group showed the need to implement their electoral right in the formal sense. Of course, there may be many factors in this situation, but undoubtedly, attention is drawn to the lack of a sense of agency among young voters. This has been confirmed by my research on life views (I studied pro-developmental views according to T. Zysk (1990), including a sense of agency and trust towards others and the world). The studied subjects were students before graduation (Kanclerz, 2015: 128-228), hence, among others, potential voters aged 18-29 years. A lot of the surveyed students were convinced that their choices could not influence the politics or change authorities $(44,1 \%)$. The vast majority of students surveyed $(82,5 \%)$ were convinced that public life is governed by corruption and promoting one's own interests. The pre-election cam- 
paign, unfortunately, could only confirm the voters in this sentiment. Politicians, focused on the attack of their opponents and detached from the matters of citizens, do not inspire confidence in voters. The surveyed students clearly expressed this when they declared their trust in others and in the world. Only one in four respondents $(24,7 \%)$ believed that political institutions act in the name of social good.

In such an atmosphere, even the best conducted campaign on electoral activity may not be effective. While the turnout in the European Parliament elections has increased significantly among all voters, it unfortunately seems that young people in the European Parliament elections have shown politicians a 'red card' through their low involvement. A completely different and interesting issue is that of the qualitative choices made by young people. It is worth realizing that at least theoretically, they vote for certain programmes, they support candidates because of certain views 7 . In the European Parliament elections, every fifth vote of young voters was cast for Confederation, a party declaring itself to be anti-systemic. The programme of Confederation is focused on building a sovereign state with a strong army and Polish currency. The party also supports the idea of protecting children and youth from homophobic propaganda. The politicians of Confederation also declare the restoration of the death penalty ${ }^{8}$, and, in the context of the elections to the European Parliament, are in favour of leaving the European Union, while emphasising their strong nationalistic commitment ${ }^{9}$. The language of the politicians of Confederation and the strengthening the patterns of exclusion of certain social groups are the main worrying issues that emerge when we analyze more closely the activities of Confederation in the space of social life. Unfortunately, only the indication of some disturbing signals, in the context of the development of civic society, which contemporary youth have "sent" to us during the electoral process, is a prelude to an in-depth study on the civic responsibility of the young generation. The polarisation of political views, low electoral activity and radicalisation of the worldview are noteworthy. The polarisation of political views, diversity in moral and ideological issues, is undoubtedly a certain disappearance of the collec-

7 Of course, in the literature on the subject one can also find different perspectives, read for example W. Eichelberger, Poland on the couch, Newsweek 14.062015 from the website https://www. newsweek.pl/polska/spoleczenstwo/polacy-wybieraja-postacie-symboliczne-a-nie-polityczne-osobowosci/qgmc71x [accessed on 19.09.2019]. For the purposes of this article, however, I take into account the thesis that in theory the electoral choices should be informed.

${ }^{8}$ Information compiled from Confederation Party website, see: https://konfederacja.net/ [accessed on 23.09. 2019].

${ }^{9}$ See: https://www.polskieradio24.pl/130/4503/Artykul/2301979,Debata-Poranka-Jakie-poglady-maja-czlonkowie-Konfederacji [accessed on 23.09.2019]. 
tive worldview, about which H. Świda-Ziemba wrote in the context of research on youth (2010). Diversity as an element of development, in this case may constitute an obstacle and, observing society in a wider context, may lead to deeper social divisions, which is undoubtedly an important educational challenge for us educators. However, we must hope (and this can be seen in the turnout in older age groups) that it is a true thesis that political non-involvement of young people only wavers slightly and is rather an example of "life cycle differences", as K. Szafraniec writes (that is, it passes with age), than a generational trait, which permanently grows in young people and determines their style of political participation in the future (Szafraniec, 2011: 282). This does not, however, release adults, educators, teachers or parents from the task of shaping civic attitudes of the young generation. One of the many forms of preparing young people to play the role of a citizen, including the fulfilment of electoral law, is learning at school and acquiring knowledge and competences. Therefore, it is worth analysing how this process is going on and whether activities at school can contribute to the higher attendance expected by commentators of social life, sociologists or political scientists, which would strengthen the functioning of democracy in our country. It seems that the reflections made on this subject could contribute to further longitudinal studies ${ }^{10}$ on students and then voters.

\section{Formal education context - what young people are taught about the European Parliament election during Civics classes ${ }^{11}$}

The article will analyze the content of formal education on the subject of Civ$\mathrm{ics}^{12}$. This subject is conducted at two stages of formal education, both in primary

${ }^{10}$ Longitudinal research. A method of conducting research that allows to observe the same people over many years. These studies are based on the criterion of time and serve to understand the mechanisms of change and factors influencing behaviour (Kaczmarek, Olejnik, Springer, 2013). In the undertaken issue, such studies would provide an opportunity to observe the significance and possible impact of citizenship education on electoral attitudes.

${ }_{11}$ The article narrows the perspective of the analysis of Citizenship Education to formal education focused on the school subject of Civics which leads to shaping civic attitudes. In order to provide a full picture and possible conclusions about the needs in Citizenship Education, broader research and analysis of the whole spectrum of core curriculum, e.g. other subjects such as Polish language or history, should be conducted. It would also be interesting to analyze non-formal projects aimed at contributing to the development of civic attitudes.

${ }^{12}$ It is one of the subjects of formal education, where the content related to shaping the citizenship responsibility of students is directly determined. The most important objectives of Civics 
and various types of secondary schools. In the article I focused on the qualitative analysis of the content of intentionally selected handbooks ${ }^{13}$ for Civics juxtaposed with the analysis of the content of the core curriculum of two educational stages: primary school and secondary school. The selective analysis of secondary sources is only to signal the phenomenon of shaping civic attitudes through formal education in this area. Referring to the legal and social context of the undertaken issue, it is worthwhile to first draw attention to several interesting issues: active electoral law, developmental tasks of adolescence and early adulthood and the time when the subject of Civics is taught. Unfortunately, in the Polish education system, these topics are not coherent with each other, which, in my opinion, may contribute to the reduction of the effectiveness of the teaching process. In simple terms, citizens over 18 years of age have the right to vote. Invoking R. Havighurst, it should be stressed that individuals have a number of developmental tasks to perform in late adolescence. In the period of early adulthood it is written, among other things, that citizens take on civic responsibility (2006: 317). The developmental needs and electoral law, i.e. the issues that coincide on this matter, are not consistent with the teaching of Civics. Of course, I see the need to implement the content related to Citizenship Education already at the primary school stage, but it is important to remember about the perception capabilities of students at this age. However, I advocate the need to transfer the teaching of Civics to the final years of secondary school. The implementation of the core curriculum, in accordance with the current principles and in the initial period of secondary school, may not be accompanied by the formation of civic responsibility and greater social maturity, which can be observed in students at the end of their secondary education. When analyzing the subject of Civics it is worthwhile to refer to the core curriculum ${ }^{14}$ which lays basis for creating handbooks for students. Interesting, but at the same time puzzling is the thread of the amount of proposed content to be implemented. Taking into account the school year calendar 2019/2020, it is worth quoting an example from a primary school. In the first half of the year, students will be un-

include, among others: knowledge of justifying the importance of democratic procedures in the life of school and group, understanding in the field of civic activity or knowledge of the political system (quoted from: Curriculum basis of the subject Civics on the website https://www.ore.edu.pl/wp-content/uploads/2018/03/podstawa-programowa-ksztalcenia-ogolnego-z-komentarzem.-szkola-podstawowa-wos.pdf [access: 20.09.2019]).

${ }^{13}$ Qualitative analysis in which the method of data collection is to search for secondary sources (quoted after: Rubacha, 2018: 157).

${ }^{14}$ Curriculum basis for general education with commentary. Primary school. Civics, from the website https:/www.ore.edu.pl/wp-content/uploads/2018/03/podstawa-programowa-ksztalcenia-ogolnego-z-komentarzem.-szkola-podstawowa-wos.pdf [accessed on 29.09.2019]. 
der 17 weeks at school, in the next half of the year about 20 weeks. This gives the teacher the opportunity to schedule about 72 lessons (in a version that takes into account the incomplete weeks at school). However, when we analyze the quantitative basis of the curriculum, it turns out that the legislator has indicated 65 topics in terms of teaching content (Core curriculum, 2018: 11-15). Theoretically, therefore, a teacher is able to implement the core curriculum. However, it is worth noting the conditions of the functioning of the school (days off, school events, class outings, trips). At the same time, the legislator proposes the teaching content in the form of extremely complex topics, often requiring the introduction of a lot of information and facts. One of the examples can be related to the acquisition of knowledge on the functioning of the European Union. In point XII, section 2 of the Core Curriculum we read: "The student lists the objectives of the European Union's activities; he or she finds information about the political biography of the Fathers of Europe and Polish citizens performing important functions in the EU institutions" (Core Curriculum, 2018: 15). Thus, even if we take into account that at earlier stages of education the student has acquired general knowledge of the origins and functioning of the European Union, the above mentioned issue seems to be extremely complex for a 45-minute lesson. However, when we analyse the textbook (Krzesicki, Kur, Poręba, 2018) referring to the above mentioned core curriculum, it is worth noting first of all that it contains 38 topics. The analysis of the content of this handbook demonstrated that it refers to the entire core curriculum. However, several issues from the core curriculum are combined in one piece in the handbook. The result is the realization of the subject, which students learn for one school year, in a very superficial way. The amount of the planned contents of education and the multitude of issues to be realized allow the teachers only to mention certain information. Referring to the analysis of the contents of the handbook for primary school, it is worth noting that the authors devote only 2,5 pages to the issue of functioning in the European Community.

Presenting the topic of "In the Common Europe", the authors raise such issues as: MEPs, the benefits of EU membership, the rights of EU citizens and European programmes (Krzesicki, Kur, Poręba, 2018: 165-168). There is a lot of basic information missing in the discussed topic. Among other things, the basic structures of the European Union are not mentioned, and the study does not contain information on when Poland joined the Community. Of course, it should be taken into account that the handbook is only one of the aids that a teacher can use during lessons. It would therefore, make sense to ask whether other materials and content provided by the teacher are complementary to the information in the handbook and to what extent they build civic or European awareness among pupils? It would 
also be interesting to examine the students' understanding of the content of the handbook. My thesis about the selectivity of the information provided and its excessive generality suggests that the multiplicity of topics required by the core curriculum is not conducive to building knowledge from the big picture to the small details. In the context of the analysed subject, it should also be stressed that there are no topics that would facilitate civic attitudes. The authors do mention the MEPs in a few sentences, but there is no indication that they come from direct elections. Let alone that students are not informed that we as citizens are the ones who influence them. Therefore, the contents of the handbooks analyzed does not include any strategy of Citizenship Education, which focuses on preparing for the role of a citizen (Levine, 2012: 50) in terms of the electoral process. Similar conclusions apply to the analysis of textbooks for secondary schools (Janicki, Komorowski, Peisert, 2019). At the outset, it should be emphasized that in the case of the extended material (the core curriculum for Comprehensive Secondary Schools conducting an extension in the field of Citizenship Education), it seems that Poland's participation in the structures of the European Union has been more emphasized, as on the cover of the second part of the handbook ${ }^{15}$ there is both a flag of Poland as the flag of the European Union. However, the structure of the handbooks is still focused on the transfer of knowledge. Therefore, one can only hope, and at the same time expect educators and teachers to reflect on the presented content. It is also extremely important to refer to the extra content of the core curriculum of Civics, which in both primary and secondary schools should be focused on: "understanding and use of information, solving problems of communication and interaction" (Programme basis, 2018: 10-11). These aspects are much closer to the empirical concept of Citizenship Education proposed by P. Levine (2012: 50) and, essentially, the quality and manner of their implementation should be given special attention when evaluating formal Citizenship Education. As J. Raciborski claims, in the sphere of civic knowledge there are no sharp deficits in Polish society, but this state does not necessarily testify to the high civic competence of Poles (Raciborski, 2011: 225).

The selected context of the analysis of the content of handbooks constituting formal education, being a fragmentary section of the social reality in which civic attitudes are shaped, shows extremely interesting cognitive threads. Therefore, while continuing the research on the civic nature of contemporary youth, it is worthwhile not to forget about the extra-territorial (non-authoritarian) dimension

${ }^{15}$ The book analyzed for the needs of the article was the one by Janicki, Komorowski, Peisert, 2019. 
of acquiring knowledge. The teacher's person and his or her interpretation of the core curriculum and handbook content will be important here. This is in line with the ideas of P. Bourdieu and J. Passeron (2006: 289-293), who note that the teaching system is neither absolutely independent nor a mirror image of the economic system. The authors of Reproduction, however, warn that the relative autonomy of the teaching system should be seen, while at the same time noting its dependence on the structure of class relations (Bourdieu, Passeron, 2006: 302-303). Neutrality and objectivity of the teacher in the presented content are almost impossible to enforce. Especially when we adopt the perspective of Z. Kwieciński, for whom a teacher in contemporary Poland is destined to build wisdom in understanding the world and responsibility for the development of other people as a guide and translator at the same time (Kwieciński, 2012: 156). The teacher is therefore not (or should not be) an objective carrier of content. His or her involvement in the teaching process, or in fact in the learning process of the young generation, even dictates that he or she should refer to values, freedom of interpretation of certain facts or simply express his or her own feelings in the process of discussion or content analysis. Therefore, young people participating in this educational process do not remain only recipients of textbook content. It is worth bearing in mind that the behaviour, attitude and manner of presenting the subject by a teacher are not without significance for a possible broader analysis of the development of electoral attitudes.

\section{Educational consideration instead of an ending}

To sum up, I would like to raise a question: in the context of the polarization of society I mentioned (the Polish-Polish war), can we still build the civic responsibility of youth based on three important attributes (freedom, activity, reliability) (Radiukiewicz, 2016: 309) and what is our role in this respect? The answer can be found, among others, in A. Szczurek-Boruta (2019: 246), who attributes to us educators the extremely the responsible task of building a learning community based on solidarity and responsibility. This "new intellectual elite" will produce specific patterns and cultural goods, being committed to change itself and the world. It is important to stress, however, that the task of shaping such a community rests not only on teachers and educators, but on entire communities, which should take care of the future and its humanistic shape and quality of socio-cultural reality (Cybal-Michalska, 2006: 147). The formation of an individual identity cannot take place without satisfying the need for community. 


\section{Bibliography}

Bukowska X., Wnuk-Lipiński E. (2009), Obywatelskość à la polonaise - czyli jakimi obywatelami sa Polacy?, „Nauka”, 1.

Campbell D.E., Levinson M., Hess F.M. (eds.) (2012), Making civic count. Citizenship education for a New Generation, Cambridge.

Cybal-Michalska A. (2006), Tożsamość młodzieży w perspektywie globalnego świata, Poznań.

Cybal-Michalska A. (ed.) (2019), Młodzież jako przedmiot i podmiot badań pedagogicznych, Poznań.

Czapiński J., Panek T. (2015), Diagnoza społeczna 2015. Warunki i jakość życia Polaków. Raport, Warszawa.

Giddens A. (2004), Socjologia, Warszawa.

Janicki A., Komorowski J., Peisert A. (2019), W centrum uwagi. Podręcznik do wiedzy o społeczeństwie dla liceum ogólnokształcącego i technikum, vol. 1-2, Warszawa.

Kaczmarek M., Olejnik I., Springer A. (2013), Badania jakościowe - metody i zastosowania, Warszawa.

Kanclerz B. (2015), Orientacje życiowe młodzieży akademickiej, Poznań.

Kielar-Turska M. (2006), Rozwój człowieka w pełnym cyklu życia, in: Psychologia. Podręcznik akademicki, vol. I, ed. J. Strelau, Gdańsk.

Kopińska V. (2017), Edukacja obywatelska w szkole. Krytyczna analiza dyskursu podręczników szkolnych, Torun.

Kopińska V. (2019), Szkoła jako miejsce antyedukacji obywatelskiej, Warszawa.

Krzesicki P., Kur P., Poręba M. (2018), Wiedza o społeczeństwie. Podręcznik. Szkoła podstawowa, Warszawa.

Kwieciński Z. (2012), Pedagogie postu. Preteksty - konteksty - podteksty, Kraków.

Levine P. (2012), Education for a Civil Society, in: Making civic count. Citizenship education for a New Generation, eds. D.E. Campbell, M. Levinson, F.M. Hess, Cambridge.

Newsweek (2015), Polska na kozetce, https://www.newsweek.pl/polska/spoleczenstwo/polacy-wybieraja-postacie-symboliczne-a-nie-polityczne-osobowosci/qgmc71x [access: 19.09.2019].

Nikitorowicz J. (2009), Ojczyzna - obczyzna - obywatelskość, in: Patriotyzm a wychowanie, eds. E.J. Kryńska, J. Dąbrowska, A. Szarkowska, Białystok.

Ośrodek Rozwoju Edukacji (2018), Podstawa programowa kształcenia ogólnego z komentarzem, https://www.ore.edu.pl/wp-content/uploads/2018/03/podstawa-programowa-ksztalcenia-ogolnego-z-komentarzem.-szkola-podstawowa-wos.pdf.

Peret-Drążewska P. (2014), Współczesna młodzież postrzegana z perspektywy rówieśników, Poznań.

Polskie Radio 24 (2019), Debata poranka. Jakie poglądy maja członkowie Konfederacji?, https://www. polskieradio24.pl/130/4503/Artykul/2301979,Debata-Poranka-Jakie-poglady-maja-czlonkowie-Konfederacji [access: 23.09.2019].

Raciborski J. (2011), Obywatelstwo w perspektywie socjologicznej, Warszawa.

Radiukiewicz A. (2016), Kobiety działaczki - ograniczenia i realizacje roli, „Rocznik Lubuski”, vol. 42, part 1.

Rokeach M. (1968), Beliefs, Attitudes and Values, San Francisco.

Rubacha K. (2008), Metodologia badań nad edukacją, Warszawa.

Sears D.O., Huddy L., Jervis R. (eds.) (2008), Psychologia polityczna, Kraków. 
Solarczyk-Szwec H. (2007), Edukacja obywatelska młodzieży i dorosłych wobec przemocy politycznej - działania na pograniczu aktywności społecznej, oświatowej i kulturalnej, „Rocznik Andragogiczny".

Szafraniec K. (2011), Młodzi 2011, Warszawa.

Szafraniec K. (2012), Dojrzewający obywatele dojrzewającej demokracji. O stylu politycznej obecności młodych, Warszawa.

Szafraniec K. (2019), Młodzi 2018. Cywilizacyjne wyzwania. Edukacyjne konieczności, Warszawa.

Szafraniec K., Wernerowicz M. (2017), Obecność młodych w sferze publicznej, in: Zmiana warty. Młode pokolenie a transformacje we wschodniej Europie i Azji, ed. K. Szafraniec, Warszawa.

Szczurek-Boruta A. (2019), Społeczne identyfikacje i tożsamość młodych Europejczyków, Poznań.

Świda-Ziemba H. (2010), Młodzież PRL. Portrety pokoleń w kontekście historii, Kraków.

Turowski J. (2001), Socjologia. Małe struktury społeczne, Lublin.

Wnuk-Lipiński E. (2005), Socjologia życia publicznego, Warszawa.

Wojtasik W. (2010), Specyfika rywalizacji politycznej w wyborach do Parlamentu Europejskiego, „Doctrina", VII.

Zysk T. (1990), Orientacja prorozwojowa, w: Orientacje społeczne jako element mentalności, eds. J. Reykowski, K. Skarżyńska, M. Ziółkowski, Poznań.

\section{Netography}

https://europarl.europa.eu/election-results-2019/pl/frekwencja/

https://konfederacja.net/

https://men.gov.pl

https://natemat.pl/181779,slownik-wojny-polsko-polskiej

https://opinie.wp.pl/coraz-wiecej-polakow-chce-wyjsc-z-unii-europejskiej-sondaz-dla-

-wp6191203265427073a

https://pkw.gov.pl/

https://www.ipsos.com/pl-pl

https://www.newsweek.pl/polska/spoleczenstwo/polacy-wybieraja-postacie-symboliczne-a-niepolityczne-osobowosci/qgmc71x

https://www.polskieradio24.pl/130/4503/Artykul/2301979,Debata-Poranka-Jakie-poglady-maja-czlonkowie-Konfederacji

https://wyborcza.pl/naszaeuropa/7,168189,24795688,czy-pis-kupuje-glosy-a-koalicjaeuropejskaniema-programu.html 
